\title{
Inhalation of cobalt by sensitised guinea pigs: effects on the lungs
}

\author{
Per Camner, Anders Boman, Anne Johansson, Margot Lundborg, Jan E Wahlberg
}

\begin{abstract}
Two groups, each of six guinea pigs, were sensitised by the application of cobalt chloride $\left(\mathrm{CoCl}_{2}\right)$ on the skin on day $0,2,7$, and 9 and the establishment of contact allergy was confirmed by patch testing on day 21 . A further six animals were not sensitised. Starting on day 42 one sensitised group and the non-sensitised group were exposed by inhalation to $2 \cdot 4$ $(0.8) \mathrm{mg}$ (mean (SD)) $\mathrm{Co}$ in the form of $\mathrm{CoCl}_{2}$ for six hours a day for two weeks. After exposure the lungs were lavaged and the cells obtained were studied by light and electron microscopy. In the sensitised exposed group much more lavage liquid was retained in the lungs than in the other two groups; although more liquid was instilled in the lungs of this group, on average only 5 (range $2 \cdot 5-10$ ) $\mathrm{ml}$ were recovered compared with $10 \mathrm{ml}$ in all animals in the other two groups. In the sensitised exposed group, the percentage of neutrophils and eosinophils tended to be higher than in the non-sensitised exposed group. The results indicate that the lungs of guinea pigs allergic to contact with Co react differently to inhaled Co compared with those of non-sensitised ones.
\end{abstract}

(British Fournal of Industrial Medicine 1993;50:753-757)

Workers in hard metal industries may develop so called hard metal pneumoconiosis as well as asthma. ${ }^{1-5}$ These diseases are thought to be caused mainly by cobalt $(\mathrm{Co})$. Inhalation of $\mathrm{Co}$ as powder

Section of Lung Medicine, Institute of Environmental Medicine, Karolinska Institute, S-104 01 Stockholm, Sweden

P Camner, A Johansson, M Lundborg

Department of Occupational Dermatology, National Institute of Occupational Health, S-171 84 Solna, Sweden

A Boman, JE Wahlberg

Department of Ultrastructure Research, The Wenner-Gren Institute, University of Stockholm, S10691 Stockholm, Sweden

A Johansson or oxide has produced fibrotic changes in animals. ${ }^{67}$ Also, exposure to Co in soluble form in concentrations below $0.1 \mathrm{mg} / \mathrm{m}^{3}$ has been shown to be associated with a pronounced increase in the prevalence of asthma. ${ }^{8}$ Inhalation of soluble Co in a concentration of around $1 \mathrm{mg} / \mathrm{m}^{3}$ has induced nodular accumulations of alveolar epithelial type II cells in rabbits, together with accumulation of macrophages..$^{10}$ It is not known whether or not immunological mechanisms are involved in the development of the lung diseases caused by Co. Co can cause allergic reactions in the skin, however (type IV-contact allergy). ${ }^{11}$ The purpose of our present study was to investigate whether the lungs of guinea pigs allergic to contact with Co reacted differently on inhalation exposure to Co than guinea pigs not sensitised to cobalt.

\section{Material and methods}

ANIMALS AND DESIGN

Guinea pigs were chosen as experimental animals because of their sensitivity to contact allergens, the availability of standardised methods for sensitisation, and because their responses are similar to human type IV reactions. ${ }^{12}$ Sixteen guinea pigs were sensitised to $\mathrm{Co}^{2+}$ by a cumulative contact enhancement test. Sensitisation was assessed with patch tests and from the sensitised animals two groups of six animals were randomly chosen. One sensitised group and one non-sensitised group (also six animals) were exposed to $2.4 \mathrm{mg} / \mathrm{m}^{3}$ of $\mathrm{Co}$ in the form of $\mathrm{CoCl}_{2}$ in exposure chambers for six hours a day for two weeks. The other sensitised group was exposed to filtered air only in an exposure chamber. The day after the last exposure all animals were killed by an overdose of sodium pentobarbitone and their lungs were excised. The left upper lobe was removed and taken for light and electron microscopy. The rest of the lung was lavaged and the cells obtained were studied by electron microscopy.

\section{SENSITISATION}

The sensitisation of the animals was carried out by a modification of the cumulative contact enhancement test method omitting the intradermal Freunds 
complete adjuvant injection on day $7 . .^{1314}$ The experiments were carried out with female DunkinHartley guinea pigs from AB Sahlins Försöksdjursfarm, Malmö, Sweden. The animals' weight ranged between 300 and $350 \mathrm{~g}$. An area of fur $6-8 \mathrm{~cm}^{2}$ over the shoulders was removed with electric clippers. On days $0,2,7$, and 9 a patch containing $\mathrm{CoCl}_{2}\left(5 \%\right.$ in $\left.\mathrm{H}_{2} \mathrm{O}\right)$ was placed on the skin under occlusion for 24 hours. On day 21 a provocation test by a patch test technique with Finn chambers was performed as reported previously. ${ }^{15}$ The animals were challenged with $\mathrm{CoCl}_{2}$ $(1,0.5$, and $0.1 \%$ in $0.9 \% \mathrm{NaCl}$ solution). The reaction of the skin was evaluated with a four-grade scale: $0=$ no reaction, $+=a$ patchy erythema, $++=$ confluent erythema, $+++=$ erythema and oedema. The minimum criterion for a positive reaction in the two sensitised groups was at least ++ to $1 \% \mathrm{CoCl}$. The unexposed group was not challenged to avoid exposure to Co before inhalation exposure.

\section{INHALATION EXPOSURE}

The inhalation exposure started 21 days after confirmation of the contact allergy on day 21. During the whole exposure period all animals were kept in $0.6 \mathrm{~m}^{3}$ exposure chambers made of stainless steel (six guinea pigs in each chamber). ${ }^{16}$ Three sensitised animals and three non-sensitised animals were placed in each of the two chambers where the Co exposure took place. In the third chamber six sensitised animals were exposed to filtered air. The average concentration of $\mathrm{Co}$ in the two chambers was $2.4(0.8) \mathrm{mg} / \mathrm{m}^{3}$ ((mean (SD)) with $2 \cdot 2(0.6)$ $\mathrm{mg} / \mathrm{m}^{3}$ in one chamber and $2.5(0.9) \mathrm{mg} / \mathrm{m}^{3}$ in the other. The Co aerosol was produced with an ultrasonic nebuliser (DeVilbiss $35 \mathrm{~B}$ ). The mass median aerodynamic diameter was about $1 \mu \mathrm{m}$ as measured with an impactor. ${ }^{17}$ Metal concentration was estimated by sucking air through a filter (Sartorius, $100 \mathrm{M}$, pore size $0.8 \mu \mathrm{m}$ ) and analysing metal deposited on the filter by atomic absorption spectrophotometry (Varian AA6).

\section{LUNG LAVAGE}

The lungs were lavaged with $2 \mathrm{ml}$ Hank's balanced salt solution without $\mathrm{Ca}^{2+}$ and $\mathrm{Mg}^{2+}$ at $37^{\circ} \mathrm{C}$ under

Table 1 Demonstration of contact allergy to $\mathrm{Co}^{2+}$ in guinea pigs sensitised according to a modified cumulative contact enhancement test. The number of positive animals for each challenge concentration is given $(n=16)$

\begin{tabular}{lllll}
\hline & \multicolumn{4}{l}{ Challenge concentration (\%) } \\
\cline { 2 - 5 } Time to test & 1 & $0 \cdot 3$ & $0 \cdot 1$ & Control (saline) \\
\hline $24 \mathrm{~h}$ & 16 & 15 & 11 & 0 \\
$48 \mathrm{~h}$ & 16 & 14 & 11 & 0 \\
\hline
\end{tabular}

gentle massage. This procedure was repeated until $10 \mathrm{ml}$ lavage fluid had been collected. In healthy guinea pigs this usually required six lavages. The lavage fluid was centrifuged at $300 \mathrm{~g}$ for 10 minutes at room temperature and resuspended in Hank's solution. The number of cells were counted in a Bürker chamber.

\section{LIGHT MICROSCOPY}

Paraffin sections prepared from the lung tissue were stained with haematoxylin and eosin. Particular attention was paid to inflammatory lesions and the growth pattern of type II cells.

\section{ELECTRON MICROSCOPY}

Pieces of lung tissue and cells obtained from the lavage fluid were fixed in $2.5 \%$ glutaraldehyde in $0.1 \mathrm{M}$ cacodylate buffer, $\mathrm{pH} 7 \cdot 2$, and then in $1 \%$ $\mathrm{OsO}_{4}$ in the same buffer. After dehydration through a graded alcohol series and embedding in Polarbed 812 (Polaron), thin sections were examined with a Jeol $100 S$ electron microscope. The volume density of the type II cells in alveolar tissue was estimated from 16 randomly selected fields from each guinea pig. ${ }^{10}$

\section{Results}

SENSITISATION

The provocation test clearly showed that all animals given the cumulative contact enhancement procedure had been sensitised to Co (table 1).

\section{GROSS FINDINGS}

The most clear difference between the sensitised exposed guinea pig group and the other groups was a higher retention of lavage fluid in the first. In all animals in the sensitised unexposed group and in the non-sensitised exposed group the lungs were rinsed until $10 \mathrm{ml}$ of lavage fluid was recovered. In the sensitised exposed group the lung tissue became attenuated and it was impossible to obtain more than an average $5 \mathrm{ml}$ of lavage fluid even with an increased number of lavages (table 2). The number of lavages were $6.7(0.5)$ (mean (SD)) in the sensitised exposed group, $6.3(1.6)$ in the non-sensitised

\begin{tabular}{|c|c|c|c|}
\hline & $\begin{array}{l}\text { Sensitised } \\
\text { exposed } \\
\text { Volume (ml) }\end{array}$ & $\begin{array}{l}\text { Non-sensitised } \\
\text { exposed } \\
\text { Volume (ml) }\end{array}$ & $\begin{array}{l}\text { Sensitised } \\
\text { non-exposed } \\
\text { Volume (ml) }\end{array}$ \\
\hline Mean & $\begin{array}{l}2 \cdot 5 \\
5 \\
3 \\
5 \\
10 \\
6 \\
5 \cdot 3\end{array}$ & $\begin{array}{l}10 \\
10 \\
10 \\
10 \\
10 \\
10 \\
10\end{array}$ & $\begin{array}{l}10 \\
10 \\
10 \\
10 \\
10 \\
10 \\
10\end{array}$ \\
\hline
\end{tabular}




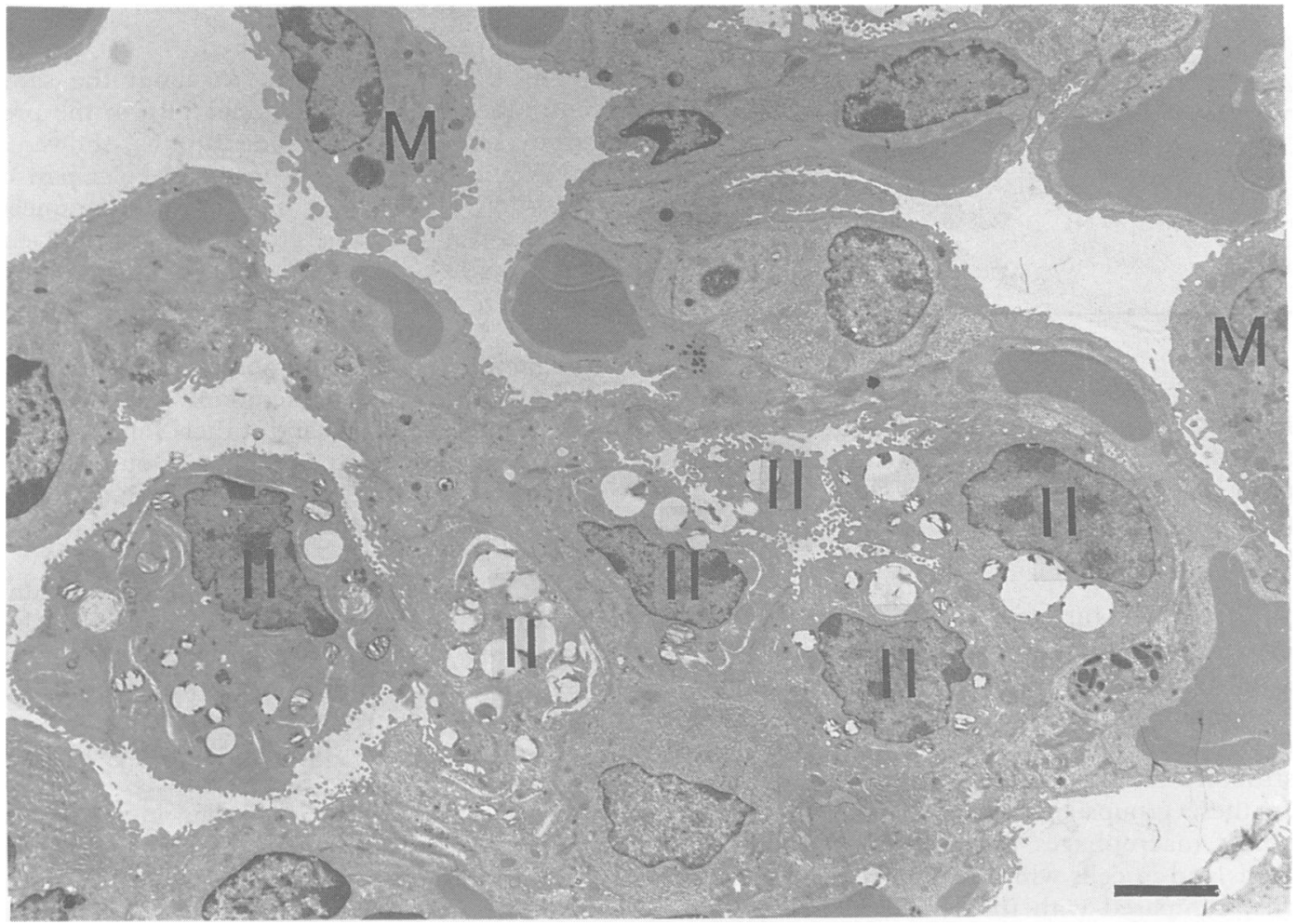

Alveolar tissue showing a nodular accumulatiom of type II cells (II) and two macrophages (M) from a guinea pig sensitised and exposed to Co. Bar $=5 \mu \mathrm{m}$.

exposed group, and $6.0(0.0)$ in the sensitised nonexposed group.

The lung weight was significantly higher in the sensitised exposed group as well as in the non-sensitised exposed group $(5.4(0.3) \mathrm{g} ; \mathrm{p}<0.01$ and 5.2 $(0.6) \mathrm{g} ; \mathrm{p}<0.02$ respectively) compared with the sensitised-non-exposed group $(4 \cdot 4(0 \cdot 6) \mathrm{g})$.

Table 3 Abnormal macrophage reaction and inflammatory changes in the lungs of guinea pigs

\begin{tabular}{lllll}
\hline & \multicolumn{4}{l}{$\begin{array}{l}\text { Macrophage reaction and inflammatory } \\
\text { changes }\end{array}$} \\
\cline { 2 - 6 } Group & Strong & Moderate & Weak & None \\
\hline Sensitised exposed & 2 & 2 & 2 & 0 \\
Non-sensitised exposed & 1 & 2 & 2 & 1 \\
Sensitised unexposed & 0 & 1 & 2 & 3 \\
\hline
\end{tabular}

LUNG TISSUE

The light microscopical study showed areas with accumulation of macrophages together with inflammatory cells such as eosinophils, neutrophils, and lymphocytes in all groups. The reaction was especially prominent and widespread in two animals in the sensitised exposed group and in one guinea pig in the non-sensitised exposed group (table 3). Nodular accumulations of type II cells were seen in both exposed groups.

Electron microscopy of the lung tissue showed no general morphological differences between the three groups. In two of the sensitised exposed guinea pigs certain areas with type II cell nodules together with accumulations of enlarged macrophages with intracellular surfactant-like inclusions were found (figure). There was, however, no significant difference in nodular accumulation of

Table 4 Percentage of type II cells found in clusters in lungs from guinea pigs

\begin{tabular}{lllllllll}
\hline & \multicolumn{1}{l}{ Number of type II cells constituting clusters (mean (SD)) } \\
\cline { 2 - 10 } Group & 1 & 2 & 3 & 4 & 5 & 6 & 7 & 8 \\
\hline Sensitised exposed & $51(9)$ & $30(6)$ & $12(3)$ & $5(4)$ & $1(2)$ & $1(2)$ & - & - \\
Non-sensitised exposed & $55(13)$ & $28(5)$ & $12(6)$ & $3(4)$ & $1(2)$ & $0 \cdot 6(1 \cdot 6)$ & - & $0 \cdot 6(1 \cdot 5)$ \\
Sensitised unexposed & $58(10)$ & $28(6)$ & $10(3)$ & $3(2)$ & $0 \cdot 3(0 \cdot 8)$ & $0 \cdot 4(1 \cdot 0)$ & - & - \\
\hline
\end{tabular}


Table 5 Percentage distribution of cells in lavage fluid from guinea pigs

\begin{tabular}{llll}
\hline Group & $\begin{array}{l}\text { Macrophages } \\
(\%(S D))\end{array}$ & $\begin{array}{l}\text { Neutrophils } \\
(\%(S D))\end{array}$ & $\begin{array}{l}\text { Eosinophils } \\
(\%(S D))\end{array}$ \\
\hline $\begin{array}{l}\text { Sensitised exposed } \\
\begin{array}{l}\text { Non-sensitised } \\
\text { exposed }\end{array}\end{array}$ & $66(21)$ & $2.3(2.5)$ & $30(24)$ \\
$\begin{array}{l}\text { Sensitised } \\
\text { unexposed }\end{array}$ & $81(10)$ & $0.7(0.8)$ & $13(4)$ \\
\hline
\end{tabular}

type II cells between the groups (table 4). Volume density of the type II cells did not differ between the groups $(0.12(0.04)$ in the sensitised exposed group, $0.13(0.04)$ in the nonsensitised exposed group, and $0.14(0.03)$ in the sensitised-unexposed group.

\section{CELLS IN LAVAGE FLUID}

The electron microscopical study showed a tendency for an increase in the percentage of neutrophils and eosinophils in the sensitised exposed group (table 5). There was no difference in macrophage ultrastructure between the two groups exposed to Co. In these groups there was an increase in the number of macrophages filled with surfactant-like inclusions and in cells with the surface lacking protrusions, compared with the sensitised unexposed group (table 6).

\section{Discussion}

A clear difference existed between the two groups exposed to Co by inhalation in the amount of retained lavage fluid; only an average of $5 \mathrm{ml}$ was collected from the sensitised exposed group compared with $10 \mathrm{ml}$ in the nonsensitised exposed group. This was despite the fact that the number of lavages was on the average higher in the sensitised group. There was also a tendency for a higher percentage of neutrophils and eosinophils in the sensitised exposed group than in the non-sensitised exposed group. It is known that more lavage fluid is retained in lungs with chronic diseases such as obstructive lung disease and emphysema. ${ }^{18}$ The result thus strongly indicates that the sensitised animals had reacted differently from the inhaled $\mathrm{Co}^{2+}$ than the non-sensitised ones. The details of this reaction will be further investigated.

Rabbits that were exposed to about the same concentration of Co as the guinea pigs in the present study but for around four months, showed a rather specific effect pattern on the alveolar part of the lungs. ${ }^{910}$ The earliest and most pronounced effect was a change in the growth pattern of alveolar type II epithelial cells, which occurred in noduli, and many of the type II cells had an abnormal appearance. Despite these noduli there was no significant increase in the volume density of the type II cells. Associated with these noduli were accumulations of macrophages and other inflammatory cells. The number of macrophages obtained by lavage was increased and some macrophages were enlarged and packed with surfactant-like inclusions. ${ }^{19}$

In our present study there was an increased lung weight, which was also found in the rabbit lung after exposure to Co. Nodular accumulation of alveolar type II cells was seen in some of the exposed guinea pigs in the present study and there was also a tendency for increased abnormal macrophage reactions in these animals. That the effect was clearer in the rabbits than in the guinea pigs might be explained by two facts. Firstly, the exposure time for guinea pigs was two weeks compared to one and four months in the experiments with rabbits. ${ }^{910}$ Secondly, there were usually higher numbers and a larger variation in the number of type II cells in the guinea pigs than in the rabbits, probably due to species differences.

The results suggest that inhalation of Co induces a reaction in lungs of guinea pigs after inhalation of soluble Co similar to that in rabbit lungs. The results also strongly indicate that sensitised guinea pigs show different pulmonary reactions to inhaled $\mathrm{Co}^{2+}$ compared with the non-sensitised ones. It seems that in sensitised guinea pigs inhalation of $\mathrm{Co}^{2+}$ induces both toxic and immunologial reactions. This response may be similar to type IV allergic reactions in patients with Co related asthma.$^{20}$ It is important to evaluate what are toxic and what are immunological effects in human diseases caused by inhalation of $\mathrm{Co}$ as this could be of value for the prevention of such diseases.

We are grateful for skilful technical assistance from

Table 6 Morphological data on macrophages obtained by lavage from guinea pigs

\begin{tabular}{lllllll}
\hline & \multicolumn{2}{l}{ Surfactant-like inclusions } & & \multicolumn{2}{l}{ Surface } \\
\cline { 2 - 3 } Group & $0-3(\%(S D))$ & $4-10(\%(S D))$ & $>10(\%(S D))$ & & Smooth (\% (SD)) & Rough (\% (SD)) \\
\hline Sensitised exposed & $71 \cdot 8(10 \cdot 5)$ & $19 \cdot 3(7 \cdot 0)$ & $9 \cdot 3(4 \cdot 6)$ & & $7 \cdot 5(2 \cdot 9)$ & $1.5(9 \cdot 2)$ \\
Non-sensitised exposed & $61 \cdot 0(10 \cdot 0)$ & $21 \cdot 0(6 \cdot 2)$ & $18 \cdot 2(10 \cdot 3)$ & & $14 \cdot 2(8 \cdot 4)$ & $23 \cdot 0(7 \cdot 0)$ \\
Sensitised unexposed & $82.3(5 \cdot 8)$ & $15 \cdot 2(3 \cdot 8)$ & $2 \cdot 7(1 \cdot 6)$ & $2 \cdot 0(2 \cdot 7)$ & $18 \cdot 7(14 \cdot 6)$ \\
\hline
\end{tabular}


Ms Ulla Bergsten, Ms Gunnel Hagelthorn, and Ms Kristina Nyberg. This study was supported by grants from the research funds of Karolinska institutet.

1 Coates EO, Watson JHL. Diffuse interstitial lung disease in tungsten carbide workers. Ann Intern Med 1971;75:709-16.

2 Kitamura H, Kitamura H, Tozawa T, Kimula Y. Cemented tungsten carbide pneumoconiosis. Acta Pathol fpn 1978;28:921-35.

3 Hartung $M$, Schaller $\mathrm{KH}$, Brand $\mathrm{E}$. On the question of the pathogenetic importance of cobalt for hard metal fibrosis of the lung. Int Arch Occup Environ Health 1982;50:53-7.

4 Balmes JR. Respiratory effects of hard-metal dust exposure. State of the Art Reviews of Occupational Medicine $1987 ; 2: 327-44$

5 Alexandersson R. Undersökningar över effekter av exposition för kobolt, exposition, upptag och lungpåverkan av kobolt $\mathrm{i}$ hårdmetallindustri. Arbete och Hälsa 1979;10:1-24.

6 Kerfoot EJ, Fredrick WG, Domeier E. Cobalt metal inhalation on minature swine. Am Ind Hyg Assoc f 1975;36:17-25.

7 Wehner AP, Busch RH, Olson RJ, Craig DK. Chronic inhalation of cobalt oxide and cigarette smoke by hamsters. $\mathrm{Am}$ Ind Hyg Assoc f 1977;38:338-46.

8 Roto P. Asthma, symptoms of chronic bronchitis and ventilatory capacity among cobalt and zinc production workers. Scand $\mathcal{F}$ Work Environ Health 1980;6(Supple 1):1-49.

9 Johansson A, Camner P, Jarstrand C, Wiernik A. Rabbit alveolar macrophages after inhalation of soluble cadmium, copper and cobalt: a comparison with the effect of soluble nickel. Environ Res 1983;31:340-54.

10 Johansson A, Robertson B, Camner P. Nodular accumulation of type II cells and inflammatory lesions caused by inhalation of low cobalt concentrations. Environ Res 1987;43: $227-43$.

11 Rystedt J, Fischer T. Relationship between nickel and cobalt sensitization in hard metal workers. Contact Dermatitis 1983;9:195-200.

12 Magnusson B, Kligman AM. Allergic contact dermatitis in the guinea pig. Springfield Ill: Charles C Thomas, 1970

13 Tsuchiya S, Kondo M, Okamoto K, Takase Y. Studies on contact hypersensitivity in the guinea pigs. The cumulative contact enhancement test. Contact Dermatitis 1982;8: 246-55.

14 Tsuchiya S, Kondo M, Okamoto K, Takase Y. Cumulative contact enhancement test. In: Andersen KE, Maibach HI, eds. Contact allergy predictive tests in guinea pigs. Curr Probl Dermatol 1985;14:208-19.

15 Wahlberg JE, Boman A. Sensitization and testing of guinea pigs with cobalt chloride. Contact Dermatitis 1978;9:128-32.

16 Holma B. Lung clearance of mono- and di-disperse aerosols determined by profile scanning and whole-body counting. Acta Medica Scandinavica 1967;supp 473:1-102.

17 Mitchell RI, Pilcher JM. Improved cascade impactor for measuring aerosol particle sizes. Industrial and Engineering Chemistry 1959;51:1039-42.

18 Finlay TN, Swenson EW, Curran WS, Huber GL, Ladman AJ. Bronchopulmonary lavage in normal subjects and patients with obstructed lung disease. Ann Intern Med 1977; 66:651-8.

19 Johansson A, Lundborg M, Wiernik A, Jarstrand C, Camner $P$. Rabbit alveolar macrophages after long-term inhalation of soluble cobalt. Environ Res 1986;41:488-96.

20 Kusaka Y, Nakano Y, Shirakawu T. Lymphocyte transformation with cobalt in hard metal asthma. Ind Health 1989; 27:155-63.

Accepted 19 October 1992 